\title{
Peripheral adaptive immunity of the triple transgenic mouse model of Alzheimer's disease
}

\author{
Isabelle St-Amour ${ }^{1,2+}$, Cristina R. Bosoi ${ }^{1,3 \dagger}$, Isabelle Paré ${ }^{4}$, Prenitha Mercy Ignatius Arokia Doss ${ }^{1,2}$, \\ Manu Rangachari ${ }^{1,2}$, Sébastien S. Hébert ${ }^{1,2}$, Renée Bazin ${ }^{4,5}$ and Frédéric Calon ${ }^{1,5^{*}}$
}

\begin{abstract}
Background: Immunologic abnormalities have been described in peripheral blood and central nervous system of patients suffering from Alzheimer's disease (AD), yet their role in the pathogenesis still remains poorly defined.

Aim and methods: We used the triple transgenic mouse model (3xTg-AD) to reproduce A $\beta$ (amyloid plaques) and tau (neurofibrillary tangles) neuropathologies. We analyzed important features of the adaptive immune system in serum, primary (bone marrow) as well as secondary (spleen) lymphoid organs of 12-month-old 3xTg-AD mice using flow cytometry and ELISPOT. We further investigated serum cytokines of 9- and 13-month-old 3xTg-AD mice using multiplex ELISA. Results were compared to age-matched non-transgenic controls (NTg).

Results: In the bone marrow of 12-month-old 3xTg-AD mice, we detected decreased proportions of short-term reconstituting hematopoietic stem cells $(0.58$-fold, $P=0.0116)$, while lymphocyte, granulocyte, and monocyte populations remained unchanged. Our results also point to increased activation of both B and T lymphocytes. Indeed, we report elevated levels of plasma cells in bone marrow (1.3-fold, $P=0.0405)$ along with a 5.4-fold rise in serum lg $\mathrm{G}$ concentration $(P<0.0001)$ in 3xTg-AD animals. Furthermore, higher levels of interleukin (IL)-2 were detected in serum of 9and 13-month-old 3xTg-AD mice $(P=0.0018)$. Along with increased concentrations of IL-17 $(P=0.0115)$ and granulocyte-macrophage colony-stimulating factor $(P=0.0085)$, these data support helper T lymphocyte activation with Th17 polarization.
\end{abstract}

Conclusion: Collectively, these results suggest that the 3xTg-AD model mimics modifications of the adaptive immunity changes previously observed in human $A D$ patients and underscore the activation of both valuable and harmful pathways of immunity in AD.

Keywords: Adaptive immune system, Hematopoietic stem cell, Th17, Inflammation, Alzheimer's disease, Neurodegenerative disease, Lymphocyte egress

\section{Introduction}

Impaired immunity is an undeniable part of Alzheimer's disease (AD) pathophysiology, although its direct contribution to disease onset and progression is still much debated [1]. The main cellular components of the adaptive immunity are B and $\mathrm{T}$ lymphocytes, ultimately responsible for humoral (antigen-specific antibody secretion)

\footnotetext{
* Correspondence: Frederic.Calon@crchudequebec.ulaval.ca

${ }^{\dagger}$ Isabelle St-Amour and Cristina R. Bosoi contributed equally to this work.

${ }^{1}$ Axe Neurosciences, Centre de recherche du CHU de Québec-Université

Laval, QC, Québec, Canada

${ }^{5}$ Faculté de pharmacie, Université Laval, QC, Québec, Canada

Full list of author information is available at the end of the article
}

and cell-mediated immunity. The adaptive immune response plays a key role in the development of adequate control against pathogens, cancer cells, and toxic molecules including misfolded tau and amyloid-beta peptide $(\mathrm{A} \beta)$ proteins $[2,3]$.

The triple transgenic (3xTg-AD) mouse model displays tau and $A \beta$ (amyloid plaques) accumulation in the brain increasing with age, as well as changes in their immune system [4-8]. In the blood of 3xTg-AD mice, we previously reported that while granulocytes are not significantly affected, total leukocytes, $\mathrm{B}$, and both $\mathrm{CD} 4^{+}$and $\mathrm{CD}^{+} \mathrm{T}$ lymphocytes are decreased compared with

(c) The Author(s). 2019 Open Access This article is distributed under the terms of the Creative Commons Attribution 4.0 International License (http://creativecommons.org/licenses/by/4.0/), which permits unrestricted use, distribution, and 
controls [4]. Interestingly, we further observed an increase in $\mathrm{CD} 4 / \mathrm{CD} 8 \mathrm{~T}$ lymphocyte ratio suggesting an imbalance between helper/cytotoxic cells [4]. These results suggest an overall deficit in adaptive immune response and are consistent with data reporting aberrant lymphocyte populations in AD individuals [9-14].

To better decipher the causes and consequences of these modulations on immune response, we investigated hematopoietic cells in primary (bone marrow) and secondary (spleen) lymphoid organs along with in vivo lymphocyte activation cues from blood cytokine and immunoglobulin $\mathrm{G}$ ( $\operatorname{IgG}$ ) production in the 3xTg-AD model. We observed decreased levels of short-term reconstituting (STR) hematopoietic stem cells in the bone marrow. Furthermore, results from immunoglobulin G (IgG) and cytokine quantification suggest increased $\mathrm{B}$ and $\mathrm{T}$ lymphocyte activation respectively. Finally, elevated levels of interleukin (IL)-2, IL-17 and granulocyte-macrophage colonystimulating factor (GM-CSF) strongly point to Th17 polarization in the $3 \times \mathrm{Tg}-\mathrm{AD}$ model of tau and $\mathrm{A} \beta$ neuropathologies.

\section{Material and methods}

\section{Animals, treatment and tissue preparation}

The 3xTg-AD mouse model of AD used in this study was developed by Oddo and colleagues [15] and bred in our animal facility. These mice harbor three mutant genes, namely genes coding for the human beta-amyloid precursor protein (APP), tau (in Thy1.2 expression cassettes), and presenilin-1 (PS1, knockin) with human mutations from familial $\mathrm{AD}\left(\mathrm{APP}_{\mathrm{swe}}, \mathrm{PS} 1_{\mathrm{M} 146 \mathrm{~V}}\right)$ and frontotemporal dementia $\left(\operatorname{tau}_{\mathrm{P} 301 \mathrm{~L}}\right)$. The $3 \mathrm{xTg}-\mathrm{AD}$ replicates many features of $A D$ including $A \beta$ and tau pathologies as well as cognitive deficits. Previous studies showed that 3xTg-AD mice fully develop neuropathological and behavior changes around 12 months of age $[6,7]$. The non-transgenic (NTg) controls used in this study were generated from the backcross of our 3xTg-AD colony with B6126SF1/J animals, maintained on a mixed B6129 background and bred in our animal facility. The Laval University Animal Research Committee (Québec, QC, Canada) approved all procedures. The animals used for post-mortem analyses of adaptive immunity are the control group (vehicle) from preclinical evaluation of human intravenous immunoglobulin (IVIg) efficacy reported earlier and included $8 \mathrm{NTg}$ and $123 x \operatorname{Tg}-\mathrm{AD}$ animals, $50 \%$ females in each group [4]. These animals received intraperitoneal administrations of sterile $0.2 \mathrm{M}$ glycine $\mathrm{pH} 4.25$, endotoxin free, twice a week for 3 months (27 injections). Mice were killed when overt $\mathrm{AD}$-like neuropathologic changes are observed (12 \pm 0.1 months) under deep anesthesia (100 mg/kg ketamine, $10 \mathrm{mg} / \mathrm{kg}$ xylazine) via terminal intracardiac perfusion of PBS containing protease and phosphatase inhibitors. Serum was prepared from intracardiac blood, and splenocytes and bone marrow (both tibia and femur) cells were isolated and stored in liquid nitrogen until used. Cytokines and chemokines were quantified before and after the development of overt AD-like neuropathological processes: blood from untreated 9- (9.0 months \pm 0.1$)$ and 13 - (12.9 months \pm 0.2$)$ month-old mice ( $N=7-8$ mice per group, 4 females in each group) was drawn from the saphenous vein, clotted on ice, and centrifuged at $5000 \mathrm{~g}$ for $5 \mathrm{~min}$ for serum recovery. Serum was frozen at $-80^{\circ} \mathrm{C}$ until used.

\section{Reagents}

Unless otherwise specified, all biochemical reagents were purchased from JT Baker (Phillipsburg, NJ, USA).

\section{Flow cytometry analysis}

To study cell marker expression, the following fluorochrome-conjugated antibodies were used as described [4, 16]: anti-CD45 (leukocyte marker; clone 30F11; eBioscience, San Diego, CA, USA), anti-CD3 (T lymphocyte marker; clone 17A2; BD Biosciences, Mississauga, ON, Canada), anti-B220 (B lymphocyte marker; clone RM4-5; BD Biosciences), anti-CD4 (helper $\mathrm{T}$ lymphocyte marker; clone GK1.5; eBioscience), anti-CD8b (cytotoxic $\mathrm{T}$ lymphocyte marker; clone eBioH35-17.2; eBioscience), anti-CD25 (regulatory $\mathrm{T}$ lymphocyte marker; clone PC61.5; eBioscience), antiFoxp3 (regulatory T lymphocyte marker; clone FJK-16s; eBioscience), anti-F4/80 (macrophage marker; clone BM8; eBioscience), anti-CD11b (macrophage and granulocyte marker; clone M1/70; eBioscience), anti-Gr1 (granulocyte marker; Ly-6G, Clone RB6-8C5; eBioscience), or relevant isotypic controls in PBS-1\%BSA. We used 7-amino-actinomycin D to assess cell viability (eBioscience). Cells were acquired and analyzed using a CyFlow ML cytometer (Partec North America, Inc., Swedesboro, NJ, USA) and FCS Express software (De Novo Software, Los Angeles, CA, USA).

Hematopoietic stem cells were quantified in bone marrow with the Mouse Hematopoietic Stem Cell Isolation Kit (BD Biosciences). It includes a lineage cocktail (lin), which contains antibodies against CD3, CD11b, B220, Ly6C, Gr1, and TER-119 to exclude differentiated cells. Both long-term reconstituting (LTR) and STR hematopoietic stem cells express the cell markers Sca- 1 and c-Kit, whereas only STR expresses CD34. Therefore, $\mathrm{lin}^{-} / \mathrm{Sca}-1^{+} / \mathrm{CKit}^{+} / \mathrm{CD} 34^{-}$cells are LTR and $\operatorname{lin}^{-} / \mathrm{Sca}-1^{+} / \mathrm{CKit}^{+} / \mathrm{CD} 34^{+}$cells are designated STR.

\section{Enzyme-linked immunosorbent assay quantification}

A mouse IgG-specific enzyme-linked immunosorbent assay (ELISA) was performed to assess IgG concentration 
in serum and cortex using goat anti-mouse $\operatorname{IgG}$ Fc-specific antibodies (Jackson ImmunoResearch Laboratories Inc., West Grove, USA) [17]. Cytokine and chemokine concentrations were determined using a multiplex ELISA (Q-plex Mouse Cytokine-Screen (16-plex); Quansys Bioscience, Logan, UT, USA). The following cytokines and chemokines were analyzed: IL- $1 \alpha$, IL-1 $\beta$, IL-2, IL-3, IL-4, IL-5, IL-6, IL-10, IL-12p70, IL-17, tumor necrosis factor (TNF) $\alpha$, granulocyte-macrophage colony-stimulating factor (GM-CSF), regulated on activated, normal $\mathrm{T}$ cell expressed and secreted (RANTES), monocyte chemoattractant protein-1 (MCP-1, also called CCL2), and macrophage inflammatory protein $1 \alpha$ (MIP- $1 \alpha)$.

\section{Enzyme-linked immunosorbent spot quantification}

Splenocytes isolated using dissociation were thawed, washed, counted, and plated on mouse anti-IgGcoated wells (Multiscreen ${ }^{\circ} \mathrm{HTS}$ filter plate; Millipore Corporation, Billerica, MA, USA) and left immobile for antibody secretion overnight at $37^{\circ} \mathrm{C}$. After washing the cells, wells were incubated with horseradish peroxidase-conjugated goat anti-mouse IgG Fc-specific antibody and mouse immunoglobulins were detected with TrueBlue peroxidase substrate (VWR, Ville Mont-Royal, QC, Canada). Each spot was counted under a dissection microscope and considered as a single IgG-secreting B cell.

\section{Immunofluorescence}

At sacrifice, a separate set of 12-month-old mice $(N=3$ $\mathrm{NTg}$ and 6 3xTg-AD, treated with glycine as described above) were perfused with PBS, brain hemispheres were recovered, fixed in $4 \%$ paraformaldehyde for $48 \mathrm{~h}$ then cryoprotected in $20 \%$ sucrose at $4{ }^{\circ} \mathrm{C}$ for $>72 \mathrm{~h}$. Then, $25-\mu \mathrm{m}$-thick sections were cut and stained as previously described [4, 17]. For detection of cerebral IgG and amyloid plaques, free-floating sections were blocked with $5 \%$ normal horse serum, $0.2 \%$ Triton X-100, and 2.4G2 antibody (to block mouse Fc receptors) in PBS. Sections were incubated overnight at $4{ }^{\circ} \mathrm{C}$, with an Alexa-Fluor 568 conjugated goat anti-mouse IgG antibody. After the overnight incubation, sections were washed in PBS and incubated for $2 \mathrm{~h}$ with an Alexa-Fluor 568 donkey anti-goat antibody (Life Technologies, Burlington, ON, Canada) at room temperature. The sections were further washed and placed in a 4',6-diamino-2-phenylindole (DAPI) for $7 \mathrm{~min}$ to stain the nuclei, then mounted on slides, incubated for $5 \mathrm{~min}$ with a $0.1 \%$ thioflavin-S solution to stain amyloid plaques, and treated with $0.5 \%$ Sudan Black to minimize the autofluorescence. After drying, the slides were coverslipped in Fluoromount mounting media. Images were acquired using a Zeiss AxioImager M2 microscope.
Analysis was performed with ZEN 2012 SP2 and ImageJ $1.51 \mathrm{~s}$ Software in the hippocampus [4].

\section{Statistical analyses}

Statistical analyses were performed using Prism 7.0a (GraphPad Software Inc., San Diego, CA, USA) and JMP 14 (SAS, Marlow, Buckinghamshire, UK). The threshold for statistical significance was set to $P<0.05$. Homogeneity of variance and normality was determined for all data sets using D'Agostino \& Pearson's normality test. When normality was verified, unpaired $t$ test was performed. When needed, logarithmic transformation was performed to reduce variances and provide more normally distributed data. Otherwise, Mann-Whitney was applied when Gaussian distribution was not confirmed. For cytokine quantification, we consulted the Statistical Consulting Service from the Université Laval. To compare the effect of the transgenes in two age groups, we used two-way ANOVA when normality of the residuals was confirmed. When normality was not confirmed, data were analyzed first using Kruskal-Wallis test followed by Dunn's multiple comparison. Then to identify the global effect of genotype, results from the two ages were grouped and analyzed using Mann-Whitney test. All statistical analyses are described in Table 1.

\section{Results}

Reduction of blood lymphocyte numbers in 3xTg-AD mice could result from multipotent progenitor decline in the bone marrow

To determine if the decrease in lymphocytes previously observed in 3xTg-AD blood [4] was generalized to primary and secondary lymphoid organs, we evaluated the cell populations of hematopoietic cells extracted from bone marrow and spleen. Comparable numbers of $\mathrm{T}$ and B lymphocytes as well as T subpopulations (helper, cytotoxic, and regulatory $\mathrm{T}$ lymphocyte) were detected in the spleen of 3xTg-AD mice compared to age-matched NTg controls (Fig. 1a). Similarly, in the bone marrow of $3 x T g-A D$ animals, the levels of lymphocytes but also monocytes and granulocytes were unchanged (Fig. 1b). In humans, reduction in hematopoietic stem cell number is observed in early $\mathrm{AD}$ and correlates negatively with age and cerebrospinal fluid $A \beta 42 / 40$ ratio [18]. To determine whether hematopoietic stem cell population could explain the decreased number of lymphocytes observed in the blood of 3xTg-AD mice, we analyzed the hematopoietic stem cell progenitor populations in the bone marrow using Sca-1, c-kit, and CD34 expression on Lin- cells. Lin- cells do not express markers normally present on lineage committed hematopoietic cells. We quantified LTR and STR hematopoietic stem cells using Sca- $1^{+} / \mathrm{cKit}^{+} / \mathrm{CD} 34^{-} / \mathrm{lin}^{-}$and $\mathrm{Sca}-1^{+} / \mathrm{cKit}^{+} / \mathrm{CD} 34^{+} /$ $\operatorname{lin}^{-}$cells, respectively $[19,20]$ (Fig. $1 \mathrm{~b}$ and Fig. 2). 
Table 1 Description of statistical analyses

\begin{tabular}{|c|c|c|c|}
\hline Figure referenced & Statistical analysis & $P$ value & Differences between means or medians ${ }^{a}$ \\
\hline $1 \mathrm{~A}$ & Unpaired $t$ test & $P>0.05$ & \\
\hline $\begin{array}{l}\text { 1B (except short-term } \\
\text { reconstituting stem cells) }\end{array}$ & Unpaired $t$ test & $P>0.05$ & \\
\hline $\begin{array}{l}\text { 1B-short-term reconstituting } \\
\text { stem cells }\end{array}$ & Mann-Whitney test & $P=0.041$ & $\begin{array}{l}\text { Median A }=0.155 ; \text { Median } B=0.075 \\
\text { Difference (Hodges-Lehmann): }-0.06\end{array}$ \\
\hline $3 A$ 一serum $\lg G$ & Mann-Whitney test & $P<0.0001$ & $\begin{array}{l}\text { Median A }=0.77 \text {; Median } B=4.505 \\
\text { Difference (Hodges-Lehmann): } 3.33\end{array}$ \\
\hline $3 A$ - cortical lgG & Mann-Whitney test & $P=0.0002$ & $\begin{array}{l}\text { Median } A=0.4287 ; \text { Median } B=0.9211 \text {; } \\
\text { Difference (Hodges-Lehmann): } 0.5244\end{array}$ \\
\hline 3A-lgG-secreting B lymphocytes & Unpaired $t$ test & $P=0.059$ & \\
\hline 3A—Plasma cells & Mann-Whitney test & $P=0.041$ & $\begin{array}{l}\text { Median } A=1.09 ; \text { Median } B=1.505 \\
\text { Difference (Hodges-Lehmann): } 0.385\end{array}$ \\
\hline 4-IL-1 $\beta, I L-3, M C P-1$, RANTES & Two-way ANOVA & $P>0.05$ & \\
\hline $\begin{array}{l}\text { 4-IL-1a, IL-4, IL-5, IL-6, IL-10, } \\
\text { IL-12p70, MIP-1a }\end{array}$ & $\begin{array}{l}\text { Kruskal-Wallis test } \\
\text { Mann-Whitney test (NTg vs. 3xTg-AD) }\end{array}$ & $\begin{array}{l}P>0.05 \\
P>0.05\end{array}$ & \\
\hline \multirow[t]{4}{*}{$4-\mid \mathrm{L}-2$} & Kruskal-Wallis test & & Not applicable \\
\hline & Dunn's multiple comparison: & $P=0.0256$ & \\
\hline & 9 months NTg vs. 3xTg-AD & $P=0.0816$ & \\
\hline & 13 months NTg vs. 3xTg-AD & $P=0.0530$ & \\
\hline $4-\| \mathrm{L}-2$ & Mann-Whitney test (NTg vs. 3xTg-AD) & $P=0.0018$ & $\begin{array}{l}\text { Median A }=7.5 ; \text { Median B }=108.7 \\
\text { Difference (Hodges-Lehmann): } 84.9\end{array}$ \\
\hline \multirow[t]{4}{*}{ 4-IL-17 } & Two-way ANOVA & & Not applicable \\
\hline & Interaction & $P=0.8262$ & \\
\hline & Age & $P=0.7464$ & \\
\hline & Genotype & $P=0.0115$ & \\
\hline \multirow[t]{4}{*}{ 4-GM-CSF } & Kruskal-Wallis test & & Not applicable \\
\hline & Dunn's multiple comparison: & $P=0.0460$ & \\
\hline & 9 months NTg vs. 3xTg-AD & $P=0.0246$ & \\
\hline & 13 months NTg vs. $3 \times \operatorname{Tg}-A D$ & $P=0.4916$ & \\
\hline 4-GM-CSF & Mann-Whitney test (NTg vs. 3xTg-AD) & $P=0.0085$ & $\begin{array}{l}\text { Median A }=88.4 ; \text { Median B }=524 \\
\text { Difference (Hodges-Lehmann): } 347\end{array}$ \\
\hline \multirow[t]{4}{*}{ 4-TNFa } & Kruskal-Wallis test & & Not applicable \\
\hline & Dunn's multiple comparison: & $P=0.0135$ & \\
\hline & 9 months NTg vs. 3xTg-AD & $P=0.0179$ & \\
\hline & 13 months NTg vs. 3xTg-AD & $P=0.3412$ & \\
\hline 4-TNFa & Mann-Whitney test (NTg vs. 3xTg-AD) & $P=0.0050$ & $\begin{array}{l}\text { Median A = 18.4; Median B = 86.9; } \\
\text { Difference (Hodges-Lehmann): } 65.2\end{array}$ \\
\hline
\end{tabular}

GM-CSF granulocyte-macrophage colony-stimulating factor, IL Interleukin, MCP-1 monocyte chemoattractant protein-1, NTg non-transgenic animals, RANTES regulated on activated, normal T cell expressed and secreted; TNF-a, tumor necrosis factor a Parametric tests were used only when normality was verified using D'Agostino \& Pearson's normality test. For cytokine/chemokine analysis (Fig. 4), two-way ANOVA was performed when normality of the residuals was confirmed (IL-1 $\beta$, IL-3, IL-17, MCP-1, and RANTES). When normality was not confirmed, cytokine/ chemokine data were analyzed first using Kruskal-Wallis test followed by Dunn's multiple comparison. Then to identify the global effect of genotype, results from the two ages were grouped ( $N=15 \mathrm{NTg} ; N=163 \times \mathrm{Tg}-\mathrm{AD})$ and analyzed using Mann-Whitney test. Significant $P$-values are italicized ${ }^{a}$ For comparison between groups; significant data only.

Although the proportions of LTR hematopoietic stem cells were similar between groups, we observed a significant decrease of STR in 3xTg-AD animals $(0.58$ fold, $P=0.0116$, Fig. $1 \mathrm{~b})$. These cells are precursors of common myeloid progenitors and common lymphoid progenitors, which migrate to secondary lymphoid organs and produce lymphoid differentiated cells [21]. The diminution in STR observed here, likely the 


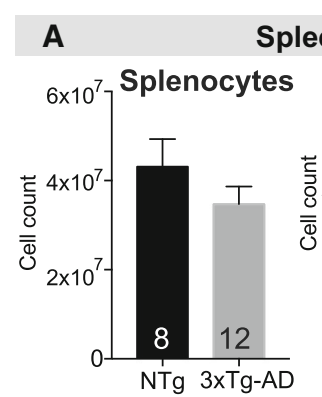

Spleen

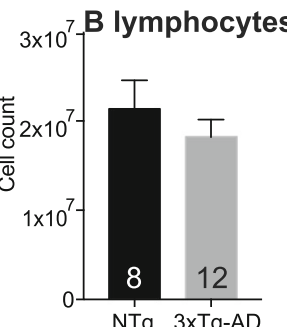

Cytotoxic T
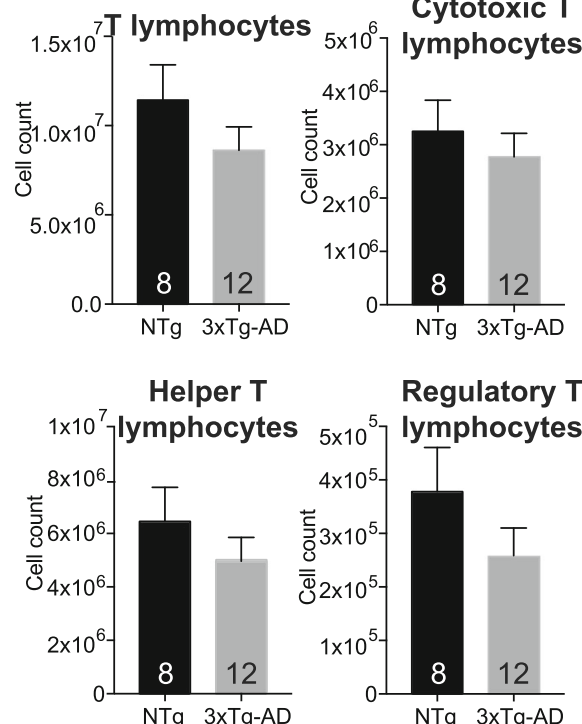

B
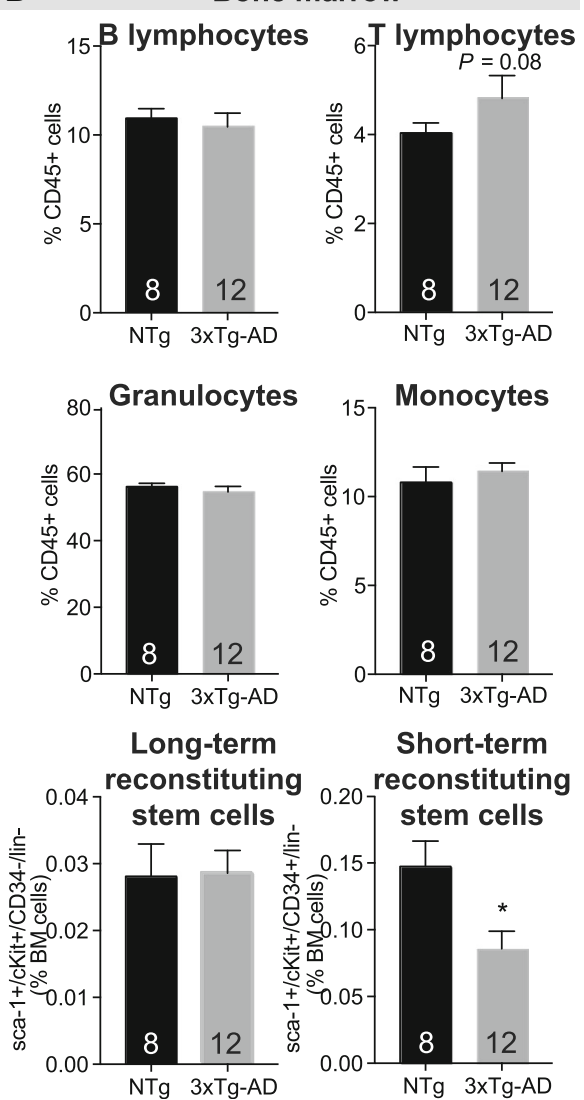

Fig. 1 Leukocyte populations in lymphoid organs of the triple transgenic (3xTg-AD) model. a Quantification of leukocyte and lymphocyte subpopulations in the spleen of 3xTg-AD mice by flow cytometry revealed similar concentrations of B and T lymphocytes compared to non-transgenic animals (NTg). b Enumeration of bone marrow cells indicates comparable proportions of B and T lymphocytes, monocytes, granulocytes, and long-term reconstituting (LTR) but reduction of short-term reconstituting (STR) hematopoietic stem cells. Data are presented as mean \pm SEM ( $N=8 \mathrm{NTg}$ and $N=12$ 3xTg-AD 12-month-old animals per group, $N$ are indicated on the graphs). Statistical analysis: Refer to Table 1. Mann-Whitney test (non-parametric) and Welch's $t$ test (parametric) was performed. ${ }^{*} P=0.0116$ compared to NTg

lymphoid-committed progenitors, could explain decreasing levels of circulating $\mathrm{B}$ and $\mathrm{T}$ lymphocytes observed in the blood of 3xTg-AD mice.

\section{Increased B lymphocyte activation in vivo in 3xTg-AD mice}

Activation and maturation of immune cells are tightly regulated to ensure adequate immune response while protecting from autoimmune response. To evaluate lymphocyte activation, we first determined the serum IgG concentration. Interestingly, we observed a 5.4-fold increase in IgG concentration in 3xTg-AD mice $(P<0.0001$, Fig. 3a). We also detected a 2.3-fold rise of IgG levels in the cortex of 3xTg-AD mice $(P=0.0002)$ but no co-localization with amyloid plaques was observed (Fig. 3a). To confirm the increase B lymphocyte activation, we next assessed the proportion of IgG-secreting B lymphocytes among total splenocytes using enzyme- linked immunosorbent spot (ELISPOT) quantification. We detected a trend toward an increase in IgG-secreting cells in the spleen (3.8-fold, $P=0.059$, Fig. 3a). Because mature B lymphocytes (plasma cells) are responsible for the production of large amounts of immunoglobulins, we next measured the number of plasma cells $\left(\mathrm{CD} 138^{+}\right.$lymphocytes) in bone marrow and observed a 1.3-fold increase of CD $138^{+}$cells in $3 x \mathrm{Tg}-\mathrm{AD}$ mice compared to controls $(P=0.0405$, Fig. 3$)$. Because sex differences in behavior and $A \beta$ load have been observed in the $3 x T g-A D$ model [6, 22-24], we further analyzed males and females separately (data not shown). Albeit low statistical power, we did not observe major sex differences. Indeed, although a trend toward more numerous plasma CD138+ cells was observed in female mice only, higher IgG levels were noted in the serum and cortex of both males and females, suggesting that the overall activation of $\mathrm{B}$ lymphocytes 


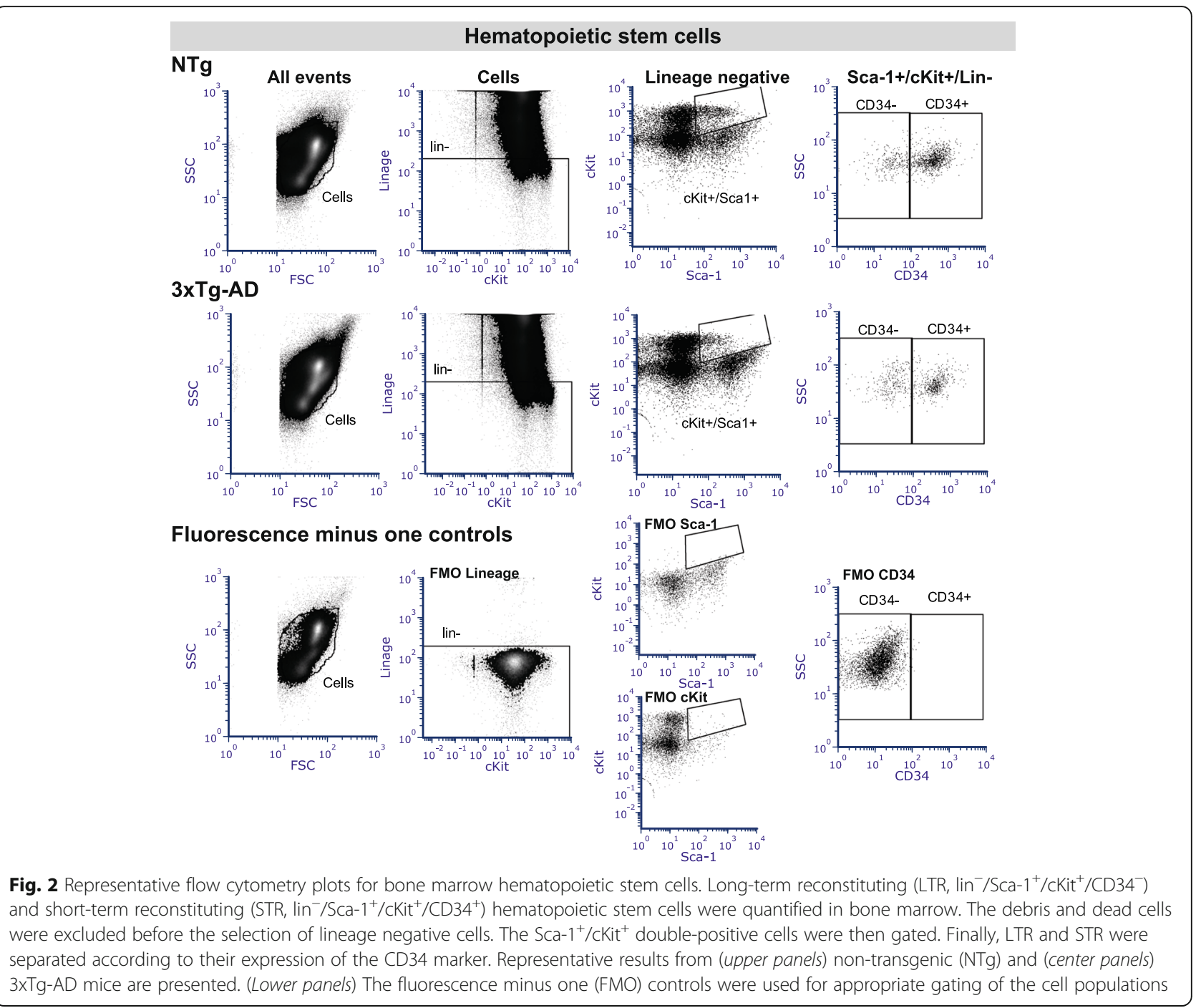

is not sex dependent. Taken together, these results provide evidence of $\mathrm{B}$ lymphocytes activation in the 3xTg-AD mouse model.

\section{Cytokine profiling supports increased activation along with Th17 polarization of T lymphocytes}

Serum cytokine quantification using multiplex ELISA probing in 9- and 13-month-old 3xTg-AD animals revealed increased levels of IL-2, TNF- $\alpha$, IL-17, and GM-CSF compared with controls but no changes in other cytokine/chemokine investigated (Fig. 4 and data not shown, detailed statistics: Table 1). Interestingly, from the panel of cytokine/chemokine tested, IL-2 is secreted almost exclusively by activated $\mathrm{CD}^{+} \mathrm{T}$ helper lymphocyte [25]. Moreover, IFN- $\gamma$, TNF- $\alpha$, and IL-2 are secreted by Th1 T lymphocyte; IL-4, IL-5, and IL-10 are the signature of Th2 lymphocytes, whereas IL-2, IL-6, IL-17, and GM-CSF relates to Th17 activation [26-28]. Therefore, our results suggest increased activation of $\mathrm{T}$ helper lymphocytes along with Th17 polarization in the 3xTg-AD model, particularly in 9-month-old mice.

\section{Discussion}

In this study, we sought to deepen our understanding of the relationship between adaptive immune-related impairments and $\mathrm{AD}$ neuropathology, using the 3xTg-AD mouse model. Lymphocyte proportions were not changed in the primary and secondary lymphoid organs investigated, but the concentrations of hematopoietic STR in the bone marrow were decreased. We also reported evidence of increased $\mathrm{B}$ and $\mathrm{T}$ lymphocyte activation along with Th17 polarization in the $3 \times \mathrm{Tg}-\mathrm{AD}$ mice, before the overt accumulation of $A \beta$ and tau pathologies. These changes also occurred in the absence of $A \beta$ and tau genetic expression in immune cells, consistent with a crosstalk between the CNS and peripheral immune cells. Interestingly, some of these modifications have also 

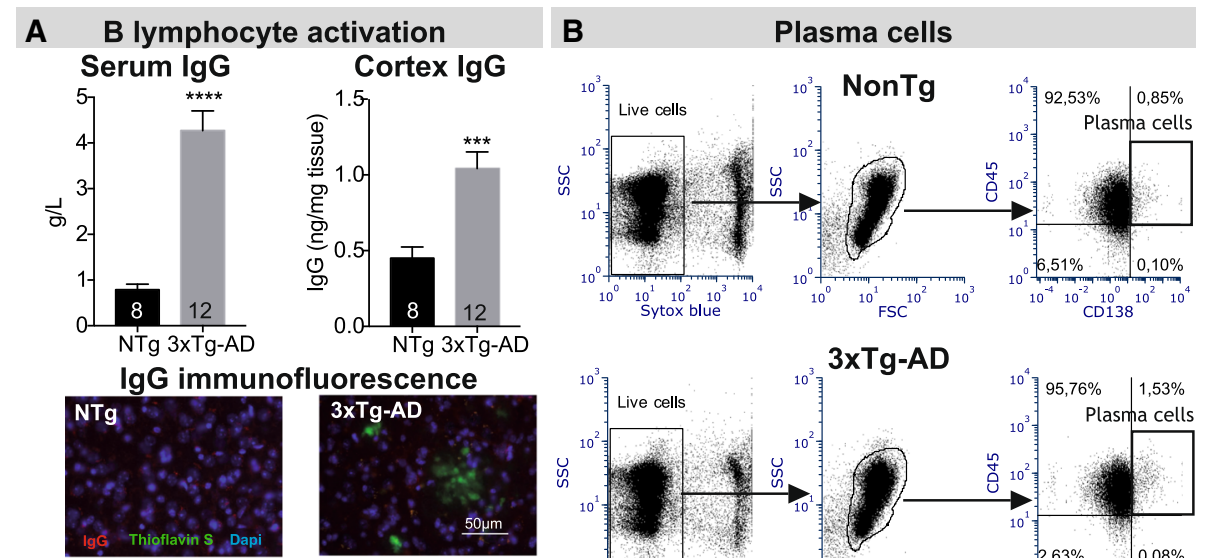

Spleen IgG-secreting Bone marrow B lymphocytes
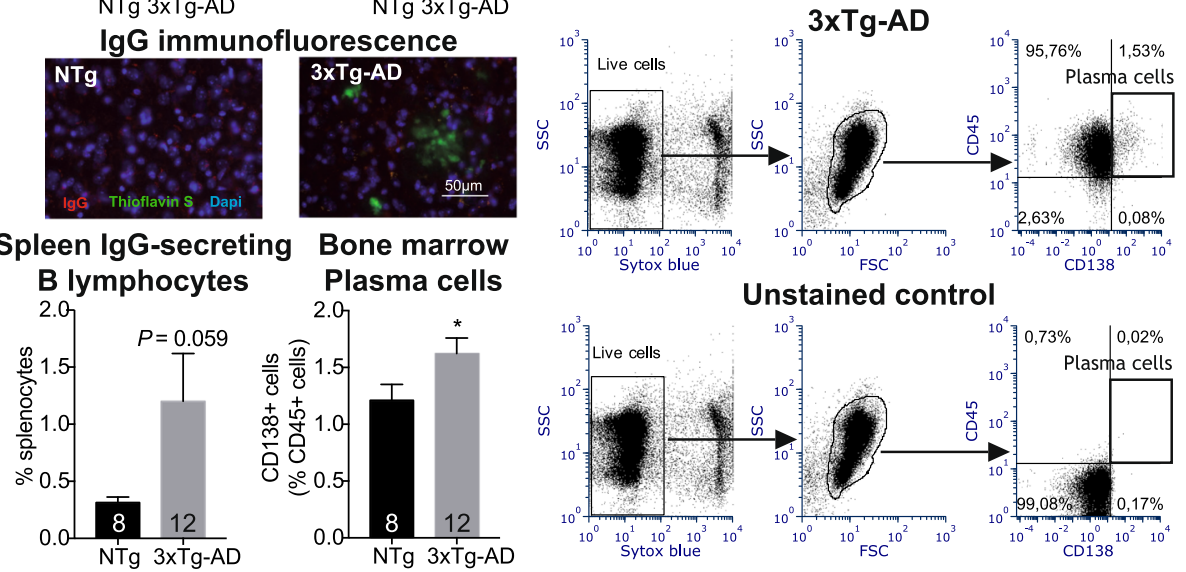

Fig. 3 Increased activation of B lymphocytes in the 3xTg-AD mouse. a (Upper panels) The rise of serum and cortex immunoglobulin G (lgG) concentrations (ELISA), and (lower panels) percentage of IgG-secreting cells (ELISPOT, spleen) and plasma cells (flow cytometry, bone marrow) strongly suggest elevated activation of B lymphocyte in the 3xTg-AD model compared to non-transgenic animals (NTg, N=8-12 12-month-old mice per group. $N$ are indicated on the graphs). (Center panels) Representative immunofluorescence staining of lgG (red), amyloid plaques (thioflavin-S, green) and nuclei (DAPI, blue) from the hippocampus of NTg and 3XTg-AD mice are presented. Statistical analysis: Refer to Table 1. Mann-Whitney test, ${ }^{*} P<0.05$; ${ }^{* *} P<0.001$; ${ }^{* * *} P<0.0001$ compared to NTg. b Representative flow cytometry plots for CD138+ bone marrow plasma cells populations

been described in $\mathrm{AD}$ patients (Table 2), validating this animal model for the study in immune changes in AD.

Cell surface markers of hematopoietic progenitors are different between humans and mice. In humans, cells expressing the cell surface antigen CD34 are capable of reconstituting long-term, multi-lineage hematopoiesis $[29,30]$. Numbers of $\mathrm{CD} 34^{+} \mathrm{CD} 45 \mathrm{RO}^{\text {low }}$ hematopoietic stem cells were found to be lower in the blood of 23 individuals with early AD compared to 25 Controls [18]. Interestingly, reduced common lymphocyte progenitors are also observed in aged normal mice [31, 32]. Therefore, decreased levels of STR reported here could reflect premature aging of the immune system in the $3 \mathrm{xTg}-\mathrm{AD}$ model, and suggest that $A \beta /$ tau pathological changes progressively developing in the brain can have an impact on immunological readouts in the periphery.

Antigen presentation, maturation of immunocompetent lymphocytes, and expansion of specific $\mathrm{T}$ and $\mathrm{B}$ lymphocytes take place in secondary organs, with the lymph nodes funneling lymph and the spleen filtering blood-derived antigens [33]. In $A D, A \beta$ peptides and tau protein have been detected in blood and/or lymph where they can migrate to secondary lymphoid organs and trigger lymphocyte activation [34-39]. Recent research suggests that the meningeal lymphatic system and the cervical lymph nodes play a key role in the clearance of cerebral $A \beta$ peptide [36, 40]. Increased naïve and decreased effector $\mathrm{T}$ cells (both $\mathrm{CD} 4^{+}$and $\mathrm{CD}^{+}$) were reported in the deep cervical lymph nodes of 5xFAD mice along with increased $\mathrm{CD}^{+}$effector cells in their brains [41]. Animal models of cerebral amyloidosis present $\mathrm{T}$ cell infiltration in the brain, which does not associate with beta-amyloid plaques [42]. In contrast however, $\mathrm{T}$ cells have not been detected in the brains of 3xTg-AD mice [43]. In a previous study, we reported a decrease of $\mathrm{T}$ lymphocytes in the blood of 3xTg-AD mice [4], associated with higher GM-CSF, IL-12, and IL-5 brain concentrations. Although IL-5 and GM-CSF can be secreted by $\mathrm{T}$ lymphocytes, levels of more $\mathrm{T}$-specific cytokines such as IL-2 or IL-17 remained similar to NTg [4]. Therefore, more extensive studies are needed to clarify the role of cerebral T cells in AD pathology.

The increased activation of lymphocytes observed in $3 x T g-A D$ mice could reflect engagement of the adaptive immune response to the removal of AD-related toxic proteins [2]. In agreement with this, we observed higher IgG concentrations in the cortex of $3 x T g-A D$ mice, although no accumulation was seen in amyloid plaques. However, chronic antigenic stress 


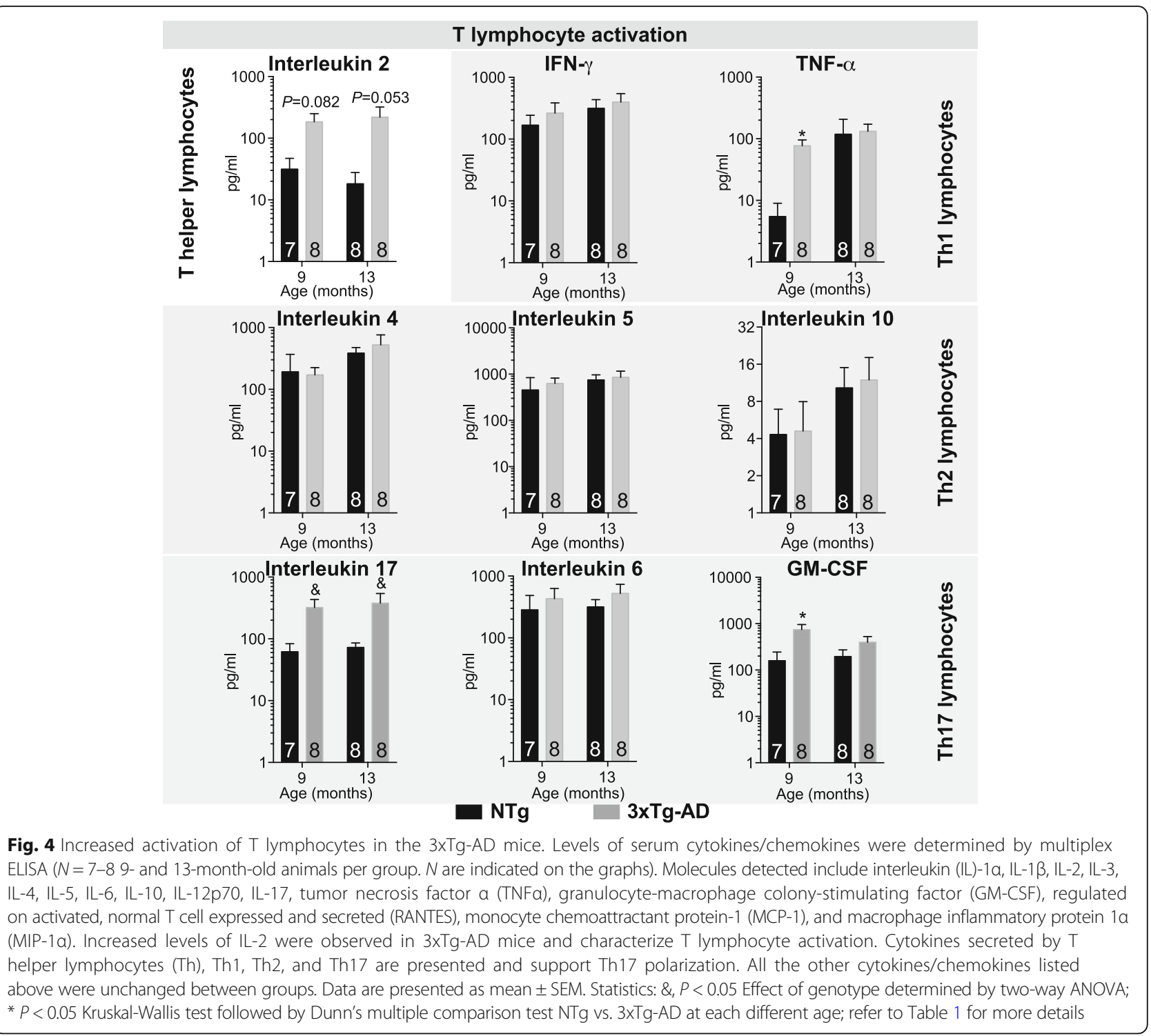

can lead to immune exhaustion [10]. Therefore, immunotherapies against $A \beta$ and tau proteins could gain from the use of both active and passive immunization strategies in order to maintain the immune balance [44-46]. In line with our results, increased activation of circulating lymphocytes $[10,11]$ together with lower number of naive $\mathrm{T}$ lymphocytes $[9,10,12]$ were reported in $\mathrm{AD}$ patients. Interestingly, cytokine quantification suggests Th17 polarization following helper $\mathrm{T}$ lymphocyte activation. Increased circulating Th17 lymphocytes have been reported in early $\mathrm{AD}$ [48]. These cells are associated with immunopathogenesis of autoimmune disorders and could promote neuroinflammation in $\mathrm{AD}[12,41]$.

The 3xTg-AD mouse was generated from presenilin 1 $\left(P S 1_{\mathrm{M} 146 \mathrm{~V}}\right)$ knockin embryos co-microinjected with $\mathrm{APP}_{\text {swe }}$ and tau $\mathrm{P}_{\mathrm{P} 01 \mathrm{~L}}$ Thy1.2 constructs [7, 15]. While transgene expression of tau and $A \beta$ is limited to the brain and spinal cord [15], $A \beta$ in the blood or peripheral organs has also been detected in this model $[6,34,36$, 49]. Increased circulating tau is also detected in $\mathrm{AD}$ patients [50-52]. It can thus be speculated that transport of $\mathrm{A} \beta$ and tau to the periphery induced an abnormal adaptive immunity response. Moreover, immune cells can cross the blood-brain barrier in $\mathrm{AD}$ and induce a cerebral immune response, which may lead to or sustain peripheral immune changes [53]. In any cases, these observations in the 3xTg-AD model lend support to the hypothesis that $\mathrm{AD}$ neuropathology may play a causal role in anomalies of peripheral adaptive immunity.

On the other hand, it should be noted that the human presenilin 1 protein expressed in the 3xTg-AD model is under the control of its murine endogenous promoter. Interestingly, in the immune system, presenilins have 
Table 2 Comparison of adaptive immunity defects observed in the 3xTg-AD model and human AD

\begin{tabular}{|c|c|c|}
\hline Immunologic modification & 3xTg-AD mice & AD patients \\
\hline $\begin{array}{l}\text { Hematopoietic } \\
\text { stem cells }\end{array}$ & $\begin{array}{l}\text { Decreased bone marrow } \\
\text { multipotent progenitors }\end{array}$ & $\begin{array}{l}\text { Reduced circulating CD34 } \\
\text { hematopoietic stem cells [18] }\end{array}$ \\
\hline B lymphocytes & $\begin{array}{l}\text { Increased plasma cells in bone } \\
\text { marrow }^{\mathrm{a}} \\
\text { Decreased in circulation [4] }\end{array}$ & Decreased in circulation $[11,72,73]$ \\
\hline $\begin{array}{l}\text { B lymphocyte } \\
\text { antibody } \\
\text { secretion }\end{array}$ & Increased $\lg G^{a}$ & Increased IgG [74] \\
\hline T lymphocytes & $\begin{array}{l}\text { Decreased circulating helper } \\
\text { (CD4) and cytotoxic (CD8) } \\
\text { lymphocytes [4] } \\
\text { Increased Th17 polarization }^{a}\end{array}$ & $\begin{array}{l}\text { Decreased }[9,14,72,73,75] \text {; no change }[11,74] \\
\text { Increased circulating Th17 lymphocytes in early AD [47] }\end{array}$ \\
\hline $\mathrm{CD}^{+} / \mathrm{CD}^{+}$ratio & Increased [4] & Increased $[14,76]$; no change $[72,73,75]$; decreased [9] \\
\hline $\begin{array}{l}\text { Plasma IL-1a } \\
\text { concentration }\end{array}$ & Decreased [59] & Decreased $[77,78] ;$ no change $[75]$ \\
\hline $\begin{array}{l}\text { Other plasma } \\
\text { cytokines }\end{array}$ & $\begin{array}{l}\text { Increased IL-2, IL-17 and GM-CSF } \\
\text { Increased IL-12, decreased } \\
\text { IL-1 } \beta \text {, IL-5, IL-6, IL-17, TNF-a, } \\
\text { IFN- } \gamma \text {, CCL2, CCL3, CCL5, CCL11, } \\
\text { and GM-CSF [59] }\end{array}$ & $\begin{array}{l}\text { Increased GM-CSF }[76,79] \\
\text { Increased or no change in IL-1, IL-6, IL-10; } \\
\text { Increased IL-4, II-12, IL-16, II-18; decreased, } \\
\text { increased, or no change in TNF-a (for review see [80]) }\end{array}$ \\
\hline
\end{tabular}

3xTg-AD triple-transgenic mouse model of Alzheimer's disease, AD Alzheimer's disease, IgG immunoglobulin G; GM-CSF granulocyte-macrophage colonystimulating factor, IL interleukin

${ }^{a}$ Current paper

been implicated in proliferation and signal transduction events in B lymphocytes as well as in thymocytes apoptosis, T lymphocyte expansion, and cytokine production [54-56]. A recent study further demonstrated that, following oxidative stress, the lymphocytes isolated from individuals with familial AD-associated presenilin $1 \mathrm{mu}-$ tations showed lower depolarization of mitochondrial membrane along with decreased apoptosis rate compared to lymphocytes from sporadic AD [57]. In addition to potential tau/A $\beta$-related immune activation, the expression of mutant presenilin 1 in immune cells could therefore trigger some of the lymphocyte impairments observed here.

Previous results from spleen lymphocyte quantification in this model have yielded controversial data. For example, reduced [8], unchanged [58], and increased [59] levels of $\mathrm{T}$ lymphocytes have been reported in the spleen of 2- and 12-month-old males, 4-month-old males, and 14- and 24-month old 3xTg-AD mice (males and females), respectively. In the study by Yang and colleagues, which reported increased levels of $\mathrm{T}$ lymphocytes, the investigators used $\mathrm{C} 57 \mathrm{Bl} / 6$ controls instead of B6129 mice [59]. The age, sex, and exact controls used in each study could therefore explain some differences observed.

In contrast with our previous results based on blood analyses [4], we did not observe lower levels of lymphocytes in the primary and secondary lymphoid organs investigated in 12-month-old 3xTg-AD mice. In healthy humans, lymphocytes present in the blood only account for approximately $2 \%$ of the total lymphocyte pool; the other $98 \%$ being distributed throughout the body [60]. Their mean transit time in the blood is evaluated to about 30 min compared to several hours in secondary lymphoid organs such as the spleen $[60,61]$. Therefore, small, statistically undetected alterations in lymphocyte composition in the spleen and bone marrow could cause major alterations in the blood [60].

Discrepancy between lymphocyte concentrations in blood and lymphoid organs between 3xTg-AD and NTg mice could also be explained by deficient egress in the 3xTg-AD animals. Sphingosine-1-phosphate (S1P), a lipid mediator, has been identified as the driving force that mediates egress of lymphocytes from lymphoid organs depending on S1P concentration gradient, which is low in lymphoid organs and high in blood and lymph [33, 61, 62]. In AD, levels of S1P are reduced in human brain samples [63, 64], whereas it has been shown to protect cultured cortical neurons against $A \beta$ toxicity [65]. S1P receptors $\mathrm{S}_{1} \mathrm{P}_{1}, \mathrm{~S}_{1} \mathrm{P}_{2}$, and $\mathrm{S} \mathrm{P}_{3}$ are expressed in cerebral endothelial cells [66] and regulate barrier integrity, which is critical to the control of central nervous system inflammation (reviewed in [67]). Therefore, impaired S1P signaling could exacerbate the neuropathological progression in AD models. FTY720 is an agonist of S1P receptor (S1PR). Although it causes the depletion of circulating lymphocytes, treating 5xFAD mice with FTY720 decreases levels of $A \beta$ peptides in the frontal cortex along with reduction of activated microglia [68]. However, the lower dose $(1 \mathrm{mg} / \mathrm{kg} /$ day $)$ was more effective 
than the higher dose $(5 \mathrm{mg} / \mathrm{kg} /$ day $)$, suggesting that suboptimal S1PR agonist could be preferred in AD therapy [68]. In AD, egress impairments could also result from increased cortisol. Indeed, whereas plasma cortisol concentrations are higher in $\operatorname{AD}[69,70]$, a robust rise of plasma cortisol in a mouse model of acute traumatic brain injury was linked to transient lymphocytopenia that was reversed by injection of S1P or rolipram, highlighting a complex and tightly regulated mechanism of lymphocyte egress [71].

\section{Conclusion}

In conclusion, our data show that a significant proportion of adaptive immunity defects observed in human $\mathrm{AD}$ are recapitulated in the $3 \times \mathrm{Tg}$ - $\mathrm{AD}$ model (Table 2), suggesting a causal role of typical $A \beta$ and tau pathologies. These alterations include modifications interpreted as both beneficial and detrimental, highlighting the complex and delicate balance between adequate antibody-directed removal of pathologic proteins and adverse autoimmune response of the adaptive immune system in AD.

\begin{abstract}
Abbreviations
3xTg-AD: Triple transgenic mouse model of Alzheimer's disease; AD: Alzheimer's disease; APP: Beta-amyloid precursor protein; Aß: Amyloid-beta peptide; ELISA: Enzyme-linked immunosorbent assay; ELISPOT: Enzyme-linked immunosorbent spot; GM-CSF: Granulocyte-macrophage colony-stimulating factor; IgG: Immunoglobulin G; IL: Interleukin; IVIg: Intravenous immunoglobulin; lin: Lineage cocktail; LTR: Long-term reconstituting hematopoietic stem cells; MCP-1 (CCL2): Monocyte chemoattractant protein-1; MIP-1a: Macrophage inflammatory protein 1a; NTg: Non-transgenic controls; PS1: Presenilin-1; RANTES: Regulated on activated, normal T cell expressed and secreted; S1P: Sphingosine-1-phosphate; S1PR: Sphingosine-1-phosphate receptor; STR: Short-term reconstituting hematopoietic stem cells; TNFa: Tumor necrosis factor alpha
\end{abstract}

\section{Acknowledgements}

The authors are grateful to Dr. Milène Vandal for fruitful scientific discussion and to Tony Tremblay for fine tuning of some cytometry protocols.

\section{Funding}

This study was supported by the Canadian Institute of Health Research (CIHR, grant ISO-102447) and Héma-Québec Foundation. IS was supported by an industrial Innovation PhD scholarship from CRSNG/FQRNT/Héma-Québec. CRB was supported by a FRQS postdoctoral scholarship. FC was supported by salary awards from the Fonds de la recherche du Québec-Santé (\#26936).

\section{Availability of data and materials}

The datasets used and/or analyzed during the current study are available from the corresponding author on reasonable request.

\section{Authors' contributions}

ISA designed the experiments, performed the animal studies and most of the postmortem analyses, analyzed the data, and wrote the manuscript. CRB participated to the data analyses and wrote the manuscript. IP participated to the animal studies, performed some of the cytometry analyses and ELISPOT quantification, and revised the manuscript. MR and PMIAP helped with the interpretation of T-lymphocyte results and revised the manuscript. SSH participated to the data analyses and revised the manuscript. RB provided funding, participated to the study design, and reviewed the manuscript. FC provided funding, conceived and designed the study, analyzed the data and wrote the manuscript. All authors read and approved the final version of the manuscript.

\section{Ethics approval}

The Laval University Animal Research Committee (Québec, QC, Canada) approved all animal procedures.

\section{Consent for publication}

Not applicable.

\section{Competing interests}

The authors declare that they have no competing interests.

\section{Publisher's Note}

Springer Nature remains neutral with regard to jurisdictional claims in published maps and institutional affiliations.

\section{Author details}

${ }^{1}$ Axe Neurosciences, Centre de recherche du CHU de Québec-Université Laval, QC, Québec, Canada. '2Département de psychiatrie et neurosciences, Faculté de médecine, Université Laval, QC, Canada. ${ }^{3}$ Centre de Recherche de I'IUCPQ-Université Laval, QC, Québec, Canada. ${ }^{4}$ Medical Affairs and Innovation, Héma-Québec, QC, Québec, Canada. ${ }^{5}$ Faculté de pharmacie, Université Laval, QC, Québec, Canada.

Received: 24 August 2018 Accepted: 27 November 2018

Published online: 05 January 2019

\section{References}

1. St-Amour I, Cicchetti F, Calon F. Immunotherapies in Alzheimer's disease: too much, too little, too late or off-target? Acta Neuropathol (Berl). 2016; 131(4):481-504.

2. Anderson KM, Olson KE, Estes KA, Flanagan K, Gendelman HE, Mosley RL. Dual destructive and protective roles of adaptive immunity in neurodegenerative disorders. Transl Neurodegener. 2014;3(1):25.

3. Cantrell D. Signaling in lymphocyte activation. Cold Spring Harb Perspect Biol. 2015;7(6):a018788.

4. St-Amour I, Paré I, Tremblay C, Coulombe K, Bazin R, Calon F. IVlg protects the 3xTg-AD mouse model of Alzheimer's disease from memory deficit and A $\beta$ pathology. J Neuroinflammation. 2014;11:54.

5. Mastrangelo MA, Bowers WJ. Detailed immunohistochemical characterization of temporal and spatial progression of Alzheimer's disease-related pathologies in male triple-transgenic mice. BMC Neurosci. 2008;9:81.

6. Vandal M, White PJ, Chevrier G, Tremblay C, St-Amour I, Planel E, et al. Age-dependent impairment of glucose tolerance in the 3xTg-AD mouse model of Alzheimer's disease. FASEB J Off Publ Fed Am Soc Exp Biol. 2015;29(10):4273-84.

7. Oddo S, Caccamo A, Kitazawa M, Tseng BP, LaFerla FM. Amyloid deposition precedes tangle formation in a triple transgenic model of Alzheimer's disease. Neurobiol Aging. 2003;24(8):1063-70.

8. Marchese M, Cowan D, Head E, Ma D, Karimi K, Ashthorpe V, et al. Autoimmune manifestations in the $3 \times T g-A D$ model of Alzheimer's disease. J Alzheimers Dis JAD. 2014;39(1):191-210.

9. Larbi A, Pawelec G, Witkowski JM, Schipper HM, Derhovanessian E, Goldeck $D$, et al. Dramatic shifts in circulating CD4 but not CD8 T cell subsets in mild Alzheimer's disease. J Alzheimers Dis JAD. 2009;17(1):91-103.

10. Pellicanò $\mathrm{M}$, Larbi $\mathrm{A}$, Goldeck $\mathrm{D}$, Colonna-Romano $\mathrm{G}$, Buffa $\mathrm{S}$, Bulati $\mathrm{M}$, et al. Immune profiling of Alzheimer patients. J Neuroimmunol. 2012; 242(1-2):52-9.

11. Speciale L, Calabrese E, Saresella M, Tinelli C, Mariani C, Sanvito L, et al. Lymphocyte subset patterns and cytokine production in Alzheimer's disease patients. Neurobiol Aging. 2007;28(8):1163-9.

12. Saresella M, Calabrese E, Marventano I, Piancone F, Gatti A, Alberoni M, et al. Increased activity of Th-17 and Th-9 lymphocytes and a skewing of the post-thymic differentiation pathway are seen in Alzheimer's disease. Brain Behav Immun. 2011;25(3):539-47.

13. Pirttilä T, Mattinen S, Frey H. The decrease of CD8-positive lymphocytes in Alzheimer's disease. J Neurol Sci. 1992;107(2):160-5.

14. Schindowski K, Peters J, Gorriz C, Schramm U, Weinandi T, Leutner S, et al. Apoptosis of $\mathrm{CD} 4+\mathrm{T}$ and natural killer cells in Alzheimer's disease. Pharmacopsychiatry. 2006;39(6):220-8. 
15. Oddo S, Caccamo A, Shepherd JD, Murphy MP, Golde TE, Kayed R, et al. Triple-transgenic model of Alzheimer's disease with plaques and tangles: intracellular Abeta and synaptic dysfunction. Neuron. 2003;39(3):409-21.

16. St-Amour I, Bousquet M, Paré I, Drouin-Ouellet J, Cicchetti F, Bazin R, et al. Impact of intravenous immunoglobulin on the dopaminergic system and immune response in the acute MPTP mouse model of Parkinson's disease. J Neuroinflammation. 2012;9:234

17. St-Amour I, Paré I, Alata W, Coulombe K, Ringuette-Goulet C, Drouin-Ouellet J, et al. Brain bioavailability of human intravenous immunoglobulin and its transport through the murine blood-brain barrier. J Cereb Blood Flow Metab Off J Int Soc Cereb Blood Flow Metab. 2013;33(12):1983-92.

18. Maler JM, Spitzer P, Lewczuk P, Kornhuber J, Herrmann M, Wiltfang J. Decreased circulating CD34+ stem cells in early Alzheimer's disease: evidence for a deficient hematopoietic brain support? Mol Psychiatry. 2006;11(12):1113-5.

19. Wilson A, Oser GM, Jaworski M, Blanco-Bose WE, Laurenti E, Adolphe C, et al. Dormant and self-renewing hematopoietic stem cells and their niches. Ann N Y Acad Sci. 2007;1106:64-75.

20. Osawa M, Hanada K, Hamada H, Nakauchi H. Long-term lymphohematopoietic reconstitution by a single CD34-low/negative hematopoietic stem cell. Science. 1996;273(5272):242-5.

21. Ichii M, Oritani K, Kanakura Y. Early B lymphocyte development: similarities and differences in human and mouse. World J Stem Cells. 2014;6(4):421-31.

22. Bories C, Guitton MJ, Julien C, Tremblay C, Vandal M, Msaid M, et al. Sex-dependent alterations in social behaviour and cortical synaptic activity coincide at different ages in a model of Alzheimer's disease. PLoS One. 2012;7(9):e46111.

23. Carroll JC, Rosario ER, Kreimer S, Villamagna A, Gentzschein E, Stanczyk FZ, et al. Sex differences in $\beta$-amyloid accumulation in 3xTg-AD mice: role of neonatal sex steroid hormone exposure. Brain Res. 2010;1366:233-45.

24. Garvock-de Montbrun T, Fertan E, Stover K, Brown RE. Motor deficits in 16month-old male and female 3xTg-AD mice. Behav Brain Res. 2019;356:305-13.

25. Hagiwara E, Abbasi F, Mor G, Ishigatsubo Y, Klinman DM. Phenotype and frequency of cells secreting IL-2, IL-4, IL-6, IL-10, IFN and TNF-alpha in human peripheral blood. Cytokine. 1995;7(8):815-22.

26. Romagnani S. T-cell subsets (Th1 versus Th2). Ann Allergy Asthma Immunol Off Publ Am Coll Allergy Asthma Immunol. 2000;85(1):9-18. quiz 18, 21

27. Mills KHG. Induction, function and regulation of $\mathrm{LL}-17$-producing $T$ cells. Eur J Immunol. 2008;38(10):2636-49.

28. Korn T, Bettelli E, Oukka M, Kuchroo VK. IL-17 and Th17 cells. Annu Rev Immunol. 2009;27:485-517.

29. Civin Cl, Strauss LC, Fackler MJ, Trischmann TM, Wiley JM, Loken MR. Positive stem cell selection—basic science. Prog Clin Biol Res. 1990;333:387401. discussion 402

30. Sutherland DR, Keating A. The CD34 antigen: structure, biology, and potential clinical applications. J Hematother. 1992;1(2):115-29.

31. Miller JP, Allman D. The decline in B lymphopoiesis in aged mice reflects loss of very early B-lineage precursors. J Immunol Baltim Md 1950. 2003; 171(5):2326-30.

32. Linton PJ, Dorshkind K. Age-related changes in lymphocyte development and function. Nat Immunol. 2004;5(2):133-9.

33. Simmons S, Ishii M. Sphingosine-1-phosphate: a master regulator of lymphocyte egress and immunity. Arch Immunol Ther Exp. 2014;62(2): 103-15.

34. Cho SM, Lee S, Yang S-H, Kim HY, Lee MJ, Kim HV, et al. Age-dependent inverse correlations in CSF and plasma amyloid- $\beta(1-42)$ concentrations prior to amyloid plaque deposition in the brain of 3xTg-AD mice. Sci Rep. 2016;6: 20185.

35. Rani P, Krishnan S, Rani CC. Study on analysis of peripheral biomarkers for Alzheimer's disease diagnosis. Front Neurol. 2017;8:328.

36. Pappolla M, Sambamurti K, Vidal R, Pacheco-Quinto J, Poeggeler B, Matsubara E. Evidence for lymphatic A $\mathrm{\beta}$ clearance in Alzheimer's transgenic mice. Neurobiol Dis. 2014;71:215-9.

37. Tatebe H, Kasai T, Ohmichi T, Kishi Y, Kakeya T, Waragai M, et al. Quantification of plasma phosphorylated tau to use as a biomarker for brain Alzheimer pathology: pilot case-control studies including patients with Alzheimer's disease and down syndrome. Mol Neurodegener. 2017;12(1):63.

38. Kovacs GG, Andreasson U, Liman V, Regelsberger G, Lutz MI, Danics K, et al. Plasma and cerebrospinal fluid tau and neurofilament concentrations in rapidly progressive neurological syndromes: a neuropathology-based cohort. Eur J Neurol. 2017;24(11):1326-e77.
39. Lue L-F, Sabbagh MN, Chiu M-J, Jing N, Snyder NL, Schmitz C, et al. Plasma levels of A 42 and tau identified probable Alzheimer's dementia: findings in two cohorts. Front Aging Neurosci. 2017;9:226.

40. Da Mesquita S, Louveau A, Vaccari A, Smirnov I, Cornelison RC, Kingsmore $\mathrm{KM}$, et al. Functional aspects of meningeal lymphatics in ageing and Alzheimer's disease. Nature. 2018;560(7717):185-91.

41. MacPherson KP, Sompol P, Kannarkat GT, Chang J, Sniffen L, Wildner ME, et al. Peripheral administration of the soluble TNF inhibitor XPro1595 modifies brain immune cell profiles, decreases beta-amyloid plaque load, and rescues impaired long-term potentiation in 5xFAD mice. Neurobiol Dis. 2017;102:81-95.

42. Ferretti MT, Merlini M, Späni C, Gericke C, Schweizer N, Enzmann G, et al. T-cell brain infiltration and immature antigen-presenting cells in transgenic models of Alzheimer's disease-like cerebral amyloidosis. Brain Behav Immun. 2016;54:211-25.

43. Movsesyan N, Ghochikyan A, Mkrtichyan M, Petrushina I, Davtyan H, Olkhanud PB, et al. Reducing AD-like pathology in 3xTg-AD mouse model by DNA epitope vaccine-a novel immunotherapeutic strategy. PLoS One. 2008;3(5):e2124. https://doi.org/10.1371/journal.pone.0002124.

44. Braczynski AK, Schulz JB, Bach J-P. Vaccination strategies in tauopathies and synucleinopathies. J Neurochem. 2017;143(5):467-88.

45. Sterner RM, Takahashi PY, Ballard ACY. Active vaccines for Alzheimer disease treatment. J Am Med Dir Assoc. 2016;17(9):862.e11-5.

46. Marciani DJ. A retrospective analysis of the Alzheimer's disease vaccine progress - the critical need for new development strategies. J Neurochem. 2016;137(5):687-700

47. Oberstein TJ, Taha L, Spitzer P, Hellstern J, Herrmann M, Kornhuber J, et al. Imbalance of circulating Th17 and regulatory T cells in Alzheimer's disease: a case control study. Front Immunol. 2018;9:1213. https://doi.org/10.3389/ fimmu.2018.01213. eCollection 2018.

48. Tahmasebinia F, Pourgholaminejad A. The role of Th17 cells in autoinflammatory neurological disorders. Prog Neuropsychopharmacol Biol Psychiatry. 2017;79(Pt B):408-16.

49. Vandal M, White PJ, Tremblay C, St-Amour I, Chevrier G, Emond V, et al. Insulin reverses the high-fat diet-induced increase in brain $A \beta$ and improves memory in an animal model of Alzheimer disease. Diabetes. 2014;63(12):4291-301.

50. Mattsson N, Zetterberg $H$, Janelidze S, Insel PS, Andreasson U, Stomrud E, et al. Plasma tau in Alzheimer disease. Neurology. 2016;87(17):1827-35.

51. Dugger BN, Whiteside CM, Maarouf CL, Walker DG, Beach TG, Sue LI, et al. The presence of select tau species in human peripheral tissues and their relation to Alzheimer's disease. J Alzheimers Dis. 2016;51(2):345-56.

52. Zetterberg H, Wilson D, Andreasson U, Minthon L, Blennow K, Randall J, et al. Plasma tau levels in Alzheimer's disease. Alzheimers Res Ther. 2013;5(2):9.

53. Hohsfield LA, Humpel C. Migration of blood cells to $\beta$-amyloid plaques in Alzheimer's disease. Exp Gerontol. 2015;65:8-15.

54. Maraver A, Tadokoro CE, Badura ML, Shen J, Serrano M, Lafaille JJ. Effect of presenilins in the apoptosis of thymocytes and homeostasis of CD8+ T cells. Blood. 2007:110(9):3218-25.

55. Ong C-T, Sedy JR, Murphy KM, Kopan R. Notch and presenilin regulate cellular expansion and cytokine secretion but cannot instruct Th1/Th2 fate acquisition. PLoS One. 2008;3(7):e2823.

56. Yagi T, Giallourakis C, Mohanty S, Scheidig C, Shen J, Zheng H, et al. Defective signal transduction in B lymphocytes lacking presenilin proteins. Proc Natl Acad Sci U S A. 2008;105(3):979-84.

57. Wojsiat J, Laskowska-Kaszub K, Alquézar C, Białopiotrowicz E, Esteras N, Zdioruk $M$, et al. Familial Alzheimer's disease lymphocytes respond differently than sporadic cells to oxidative stress: upregulated p53-p21 signaling linked with Presenilin 1 mutants. Mol Neurobiol. 2017;54(7):5683-98.

58. Baek H, Ye M, Kang G-H, Lee C, Lee G, Choi DB, et al. Neuroprotective effects of CD4+CD25+Foxp3+ regulatory T cells in a 3xTg-AD Alzheimer's disease model. Oncotarget. 2016;7(43):69347-57.

59. Yang S-H, Kim J, Lee MJ, Kim Y. Abnormalities of plasma cytokines and spleen in senile APP/PS1/Tau transgenic mouse model. Sci Rep. 2015;5:15703.

60. Westermann J, Pabst R. Lymphocyte subsets in the blood: a diagnostic window on the lymphoid system? Immunol Today. 1990;11(11):406-10.

61. Cyster JG, Schwab SR. Sphingosine-1-phosphate and lymphocyte egress from lymphoid organs. Annu Rev Immunol. 2012;30:69-94.

62. Schwab SR, Cyster JG. Finding a way out: lymphocyte egress from lymphoid organs. Nat Immunol. 2007;8(12):1295-301.

63. Couttas TA, Kain N, Daniels B, Lim XY, Shepherd C, Kril J, et al. Loss of the neuroprotective factor sphingosine 1-phosphate early in Alzheimer's disease pathogenesis. Acta Neuropathol Commun. 2014;2:9. 
64. He X, Huang Y, Li B, Gong C-X, Schuchman EH. Deregulation of sphingolipid metabolism in Alzheimer's disease. Neurobiol Aging. 2010; 31(3):398-408.

65. Malaplate-Armand C, Florent-Béchard S, Youssef I, Koziel V, Sponne I, Kriem $B$, et al. Soluble oligomers of amyloid-beta peptide induce neuronal apoptosis by activating a CPLA2-dependent sphingomyelinase-ceramide pathway. Neurobiol Dis. 2006;23(1):178-89.

66. Sp ampinato SF, Obermeier B, Cotleur A, Love A, Takeshita Y, Sano Y, et al. Sphingosine 1 phosphate at the blood brain barrier: can the modulation of S1P receptor 1 influence the response of endothelial cells and astrocytes to inflammatory stimuli? PLoS ONE. 2015; 10(7): e0133392.

67. Tsai HC, Han MH. Sphingosine-1-phosphate (S1P) and S1P signaling pathway: therapeutic targets in autoimmunity and inflammation. Drugs. 2016;76(11):1067-79

68. Aytan N, Choi J-K, Carreras I, Brinkmann V, Kowall NW, Jenkins BG, et al. Fingolimod modulates multiple neuroinflammatory markers in a mouse model of Alzheimer's disease. Sci Rep. 2016;6:24939.

69. Notarianni E. Cortisol: mediator of association between Alzheimer's disease and diabetes mellitus? Psychoneuroendocrinology. 2017:81:129-37.

70. Zvěrová M, Fišar Z, Jirák R, Kitzlerová E, Hroudová J, Raboch J. Plasma cortisol in Alzheimer's disease with or without depressive symptoms. Med Sci Monit Int Med J Exp Clin Res. 2013;19:681-9.

71. Dong T, Zhi L, Bhayana B, Wu MX. Cortisol-induced immune suppression by a blockade of lymphocyte egress in traumatic brain injury. Neuroinflammation. 2016;13(1):197.

72. Xue S-R, Xu D-H, Yang X-X, Dong W-L. Alterations in lymphocyte subset patterns and co-stimulatory molecules in patients with Alzheimer disease. Chin Med J. 2009;122(12):1469-72.

73. Richartz-Salzburger E, Batra A, Stransky E, Laske C, Köhler N, Bartels M, et al. Altered lymphocyte distribution in Alzheimer's disease. J Psychiatr Res. 2007 ; 41(1-2):174-8

74. Söllvander S, Ekholm-Pettersson F, Brundin R-M, Westman G, Kilander L, Paulie $S$. et al. Increased number of plasma B cells producing autoantibodies against A 442 protofibrils in Alzheimer's disease. J Alzheimers Dis. 2015;48(1):63-72.

75. Bonotis K, Krikki E, Holeva V, Aggouridaki C, Costa V, Baloyannis S. Systemic immune aberrations in Alzheimer's disease patients. J Neuroimmunol. 2008; 193(1-2):183-7.

76. Shalit F, Sredni B, Brodie C, Kott E, Huberman M. T lymphocyte subpopulations and activation markers correlate with severity of Alzheimer's disease. Clin Immunol Immunopathol. 1995;75(3):246-50.

77. Ray S, Britschgi M, Herbert C, Takeda-Uchimura Y, Boxer A, Blennow K, et al. Classification and prediction of clinical Alzheimer's diagnosis based on plasma signaling proteins. Nat Med. 2007;13(11):1359-62.

78. Gómez Ravetti M, Moscato P. Identification of a 5-protein biomarker molecular signature for predicting Alzheimer's disease. PLoS One. 2008;3(9):e3111

79. Tarkowski E, Wallin A, Regland B, Blennow K, Tarkowski A. Local and systemic GM-CSF increase in Alzheimer's disease and vascular dementia. Acta Neurol Scand. 2001;103(3):166-74.

80. Lee KS, Chung JH, Choi TK, Suh SY, Oh BH, Hong CH. Peripheral cytokines and chemokines in Alzheimer's disease. Dement Geriatr Cogn Disord. 2009; 28(4):281-7.

Ready to submit your research? Choose BMC and benefit from:

- fast, convenient online submission

- thorough peer review by experienced researchers in your field

- rapid publication on acceptance

- support for research data, including large and complex data types

- gold Open Access which fosters wider collaboration and increased citations

- maximum visibility for your research: over $100 \mathrm{M}$ website views per year

At $\mathrm{BMC}$, research is always in progress.

Learn more biomedcentral.com/submissions 